\title{
INDUCED SPAWNING AND LARVAL DEVELOPMENT OF VIETNAMESE KOI, Anabas testudineus (Bloch, 1792) USING SALMON GONADOTROPIN RELEASING HORMONE ANALOGUE (S-GnRHA)
}

\author{
Md. Imtiaz Rahman*), Md. Sadiqul Islam*), Md. Saddam Hossain*), Md. Ripon Ali*), Bipresh Das*), \\ Mohammad Amzad Hossain ${ }^{*}$, and Mohammed Mahbub Iqbal* \\ *) Department of Fish Biology and Genetics, Sylhet Agricultural University \\ Sylhet-3100, Bangladesh \\ *N) Department of Fisheries Biology and Genetics, Faculty of Fisheries, Mymensingh, Bangladesh
}

(Received: October 13, 2020; Final revised: March 29, 2021; Accepted: March 30, 2021)

\begin{abstract}
The present research work has been carried out to obtain evidence on breeding and embryonic growth of A. testudineus by using S-GnRHa. Fish were injected with three different doses $(0.25,0.5$, and $1.0 \mathrm{~mL} / \mathrm{kg}$ body weight) of synthetic hormone S-GnRHa each with three replications, where male brood fish received half of the doses of female. The fecundity of A. testudineus was ranged from 47,227 to 77,561 during the study period and except control group all the hormone received group ovulated within 12 hours of hormone injection. Among all groups, the highest fertilization rate $(89.33 \%$, highest hatching rate $(79.5 \%)$ as well as highest survival rate $(67.0 \%$ was obtained at $0.5 \mathrm{~mL} / \mathrm{kg}$ body weight hormone dose recipient group. The fertilized egg's diameter was recorded as $77.59 \pm 3.50 \mu \mathrm{m}$. The first cleavage had appeared within 18-25 min of fertilization and eventually the morula, blastula, and gastrula stages were observed at 3:10 h, $4 \mathrm{~h}$, and $5: 30 \mathrm{~h}$, respectively after fertilization. Larvae with distinguished head, body form and tail appendage spotted between $17-22 \mathrm{~h}$ and the larvae started hatching at $19 \mathrm{~h}$ after fertilization. The average length of larvae accounted as $105.41 \pm 3.73 \mu \mathrm{m}$. The findings of present study revealed that $0.5 \mathrm{~mL} / \mathrm{kg} \mathrm{S}-\mathrm{GnRHa}$ could be efficient dose for successful induced breeding of A. testudineus.
\end{abstract}

\section{KEYWORDS: S-GnRHa; induced breeding; Anabas testudineus; larval development}

\section{INTRODUCTION}

The climbing perch, Anabas testudineus is a wellknown airbreathing anabantoidae fish and once it was most abundantly available in Bangladesh. However, due to over exploitation, habitat destruction and lack of seed for commercial culture, the population of this species is declining day by day (Khatun et al., 2019). Therefore, Vietnamese strain of koi (A. testudineus) was introduced in Bangladesh during the year of 2011 from Vietnam having fast growth rate (Mondal et al., 2010), premium nutritive value (Paul et al., 2017) and trendy market demand and becomes one of the successful exotic fish for aquaculture in Bangladesh (Faruk et al., 2018). The Vietnamese koi have quite different morphometrics in comparing to indigenous strain of Bangladesh (Ara \& Nabi, 2018; Helmizuryani et al.,

\footnotetext{
\# Correspondence: Department of Fish Biology and Genetics, Sylhet Agricultural University. Sylhet-3100, Bangladesh

E-mail: mamzad.fbg@ sau.ac.bd
}

2020). The Vietnamese strain in aquaculture of Bangladesh have been reported to be $30 \mathrm{~cm}$ in standard length and $198.67 \mathrm{~g}$ in body weight, while indigenous strain of reaches only $14.50 \mathrm{~cm}$ in length and $63.78 \mathrm{~g}$ in weight (Ahamed et al., 2018; Hossen et al., 2017; Khatun et al., 2019).

Various spawning agents have been reported to induce the experimental breeding of A. testudineus, such as Wova-FH, Ovatide, Ovaprim, LHRHa, HCG, and PG, pituitary gland (Aktar, 2015; Nabi et al., 2020; Sarkar et al., 2005; Sukendi et al., 2019). It is most common practice to use pituitary gland (PG) and human chorionic gonadotropin (HCG) for hatchery breeding induction in Bangladesh (Amin et al., 2016; Kumar et al., 2021) but mass production and price range of these agents not handy yet. To overcome above difficulties, complementary agents like salmon gonadotropin releasing hormone analogue, $\mathrm{S}-\mathrm{GnRHa}$ is launched in Bangladesh to improve production of several aquaculture species (Amin et al., 2016; Raze et al., 2017). The synthetic analogue of $\mathrm{GnRHa}$ is 
cheaper, readily available, and efficient induced hormone being imported in Bangladesh (Mandal et al., 2016).

The embryonic development of A. testudineus was reported (Zalina et al., 2012), and in fish, embryonic development is strongly influenced by temperature, $\mathrm{pH}$, and dissolve oxygen. Research on hormonal induction and associated embryonic development will reveal key information require for mass seed production and post hatching care of this species efficiently. This recent research was aimed at exploring the embryological development of A. testudineus for better management, conservation, and commercial seed production in aquafarm using synthetic form of GnRHa.

\section{MATERIALS AND METHODS}

\section{Study Area and Duration}

The whole experiment has been carried out at commercial hatchery 'Alapur Hatchery and Fisheries' in Bangladesh, Laboratory assays and cytological studies were conducted at laboratory of Fish Biology and Genetics, Bangladesh Agricultural University, Bangladesh and the duration of the hatchery trials was for three months.

\section{Rearing and Selection of Brood Fish}

The brood fish was reared in prepared brood rearing ponds (0.08 hectare and water depth 0.9-1.1 meters) at a total of 500 mature fish of both sexes were reared. Before rearing, lime, fertilizer, and cow dung were properly applied. Brood fish were also fed twice daily at $3 \% 7 \%$ body weight with supplementary feed (protein $50 \%$ fat $8 \%$ carbohydrate $20 \%$ ash $15 \%$ fiber $1.5 \%$ calcium $2.1 \%$ and phosphorus $2.5 \%$ vitamins and mineral $1 \%$. Healthy, sexually mature broods were chosen for treatments purpose. Broods were detected by provision of their secondary sexual attributes. The mature male showed constricted abdomens with long projected genital papillae and female are easily spotted due to their however, the bulging abdomen and ringed urogenital papillae. The weight of the mature male and females were ranges from 240-320 g and 344-610 g, respectively.

\section{Induced Breeding}

Synthetic hormone S-GnRHa (Ovupin) were injected below the pectoral fin and above the lateral line of fish. Three different doses of S-GnRHa i.e., T1 (0.25 mL/kg BW), T2 (0.5 mL/kg BW), and T3 (1.0 $\mathrm{mL} / \mathrm{kg} \mathrm{BW}$ ) have been assigned to 10 pair of fishes in each with three replications and a sex ration of 1:1 maintained for all treatments. Following the hormone injection male and female fishes were held together in $2.1 \mathrm{~m} \times 1.5 \mathrm{~m} \times 1 \mathrm{~m}$ sized hapa to monitor their eggs release and spawning after 8-12 hours.

\section{Determination of Ovulation Rate}

The rate of ovulation was observed up-to for 12 hours of post injection and results were obtained by using below formula from Legendre (2000).

$$
O R(\%)=\frac{\text { No. of fish ovulated }}{\text { Total no. of fish injected }} \times 100
$$

information: $\mathrm{OR}=$ Ovulation rate

\section{Estimation of Fecundity}

The fecundity was calculated by using the formula adopted from Rahman \& Samat (2020).

$$
F=\frac{\text { No. of eggs in the sample }}{\text { Weight of the sample }} \times \text { Total egg weight }
$$

information: $F=$ Fecundity

\section{Determination of Fertilization Rate}

A small subsample of fertilized eggs from hatching jar was put on a dish measure fertilization rate to from hatching jar. Following the visual observation, fertilized eggs were identified and counted very well. The rate of fertilization was counted by using below formula.

$$
\mathrm{FR}(\%)=\frac{\text { No. of fertilized eggs }}{\text { No. of (fertilized }+ \text { no. of unfertilized })} \times 100
$$

information: $F R=$ Fertilization rate

\section{Determination of Hatching Rate}

It had taken approximate 20 to 24 hours for completion of hatching phase. A subsample was separated on a tray and amounts of the hatchings were identified and calculated by visual aid. The rate of hatching was subjected to calculate by formula (Unuma et al., 2004).

$$
H R(\%)=\frac{\text { No. of eggs hatched }}{\text { Total no. of fertilized eggs }} \times 100
$$

information: $H R=$ Hatching rate

\section{Observation of Embryonic Development Stages}

The eggs were observed under microscope until hatched (20-24 h). Observation of embryonic stages were carried out using an OLYM PUS CX21 photo microscope as well as different embryonic development stages were captured by using a camera (Rigla-32, Optikam B3 Digital camara, Italy) attached to the mi- 
croscope. By using "Image J" software diameter of different embryonic development stage was measured and analyzed.

\section{Statistical Analysis}

Raw data were treated and prepared on excel sheet and further analysis were conducted using IBM SPSS version 26. The one-way analysis of variance (ANOVA) was used to clarify the level of significance $(P<0.05)$ among all the treatments and further significant results $(P<0.05)$ of means were tested with Duncan's New Multiple Range Test (DMRT).

\section{RESULTS AND DISCUSSIONS}

It had been noticed very well that dosages of hormone strongly manipulated the percentage of eggs production and the control cluster did not ovulate in experiment. The similar trend in breeding induction were reported with Wova FH (Sarkar et al., 2005) and it's with the synthetic Ovaprim (Bhattacharyya \& Homechaudhuri, 2009) for Anabas testudineus. Among treatments, T2 or $0.5 \mathrm{~mL} / \mathrm{kg}$ dose received group showed maximum performance in respect of fertilization, hatching, survival rate compared to other hormone received groups (Table 1 ).

Again, in respect of fertilization rate $\mathrm{T}_{2}$ group showed the highest $(89.33 \%$ followed by $79.33 \%$ and $72 \%$ in $\mathrm{T}_{3}$ and $\mathrm{T}_{1}$, respectively. The hatching rates were $73.58 \% 79.5 \%$ and $64.48 \%$ in $T_{1}, T_{2}$, and $T_{3}$, respectively. The lowest hatching rate was $64.48 \%$ in $\mathrm{T}_{3}$ and highest hatching rate was $79.5 \%$ in $T_{2}$, respectively, and the difference among three doses were statistically significant $(P<0.05)$. The fecundity of $A$. testudineus was ranged from 47,227 to 77,561 during the study period (Table 2 ). The significantly highest fecundity was counted in May and the lowest in April (Table 2).

Amin et al. (2016) had reported successful induction of breeding in captive reared $A$. testudines with 2 $\mathrm{mg} / \mathrm{kg}$ for male and $7 \mathrm{mg} \mathrm{PG} / \mathrm{kg}$ for female with pituitary gland extract and ovaprim injection. A rate of fertilization $98 \pm 6.7 \%$ have been reported for same species while inducing with exogenous $\mathrm{GnRHa}$ (Mandal et al., 2016) and 90\%100\%during inducing with $1.5 \mathrm{~mL} / \mathrm{kg}$ ovaprim (Hasan et al., 2018; Kiran et al., 2013). Current success in hatching rate appeared to be quite low in contrasted previous research by Sarkar et al. (2005) and Mandal et al. (2016) who observed a high rate hatching at $90.5 \pm 3.65 \% 100 \%$ and $99 \pm 5.4 \%$ respectively. However, relatively low hatching rate has been reported with injection of commercial SGnRH as 42\%(Loh \& Ting, 2015), 75\% with synthetic hormone WOVA-FH (Behera et al., 2016) and 51\% in natural condition (Muslimin et al., 2018). Such variation could arise due to differences in rearing temperature, water circulation, and quality of selected brood.

The value of fecundity is influenced by a number of issues like size, age, environmental conditions, stocking ration, and dietary constituents (Ganias, 2017; Helmizuryani et al., 2020; Tsadik \& Bart, 2007). The present findings were differed from (Uddin et al., 2017) who reported that the absolute fecundity of Vietnamese koi, A. testudineus were 16,832-46,186 for $14-17 \mathrm{~cm}$ length and $66-89 \mathrm{~g}$ sized fish during his study period. He found the highest absolute fecundity in the month of July and lowest in April. However, Zalina et al. (2012) observed fecundity between $2,785 \pm 411.9$ and $4,851 \pm 1,415$ eggs/fish for $14-16$ $\mathrm{cm}$ length and $41-56 \mathrm{~g}$ sized female while inducing with LHRHa. This might be due to different geographic, environmental condition, and induction of breeding by using synthetic hormone. Besides, rainfall, physico-chemical parameters of water, age, and size of brood fish might be differed from the present study.

\section{Different Stages of Egg Development}

The progress of eggs started with the establishment of blastodisc (Figure 1.A) at room temperature $\left(26 \pm 0.5^{\circ} \mathrm{C}\right)$. The fertilized ovum of $A$. testudineus were characterized by spherical form, pearl-like in

Table 1. Performance of different treatments of S-GnRHa on A. testudineus

\begin{tabular}{lccc}
\hline & \multicolumn{3}{c}{ Treatments } \\
\cline { 2 - 4 } \multicolumn{1}{c}{ Parameters } & $\mathbf{T}_{\mathbf{1}}$ & $\mathbf{T}_{\mathbf{2}}$ & $\mathbf{\mathbf { T } _ { \mathbf { 3 } }}$ \\
& $\mathbf{( 0 . 2 5} \mathbf{~ \mathbf { L }} \mathbf{k g ~ B W})$ & $\mathbf{( 0 . 5 0 ~ \mathbf { ~ L } / \mathbf { k g ~ B W } )}$ & $\mathbf{( 1 . 0 0 ~ \mathbf { ~ L } / \mathbf { k g ~ B W } )}$ \\
\hline Total length (cm) & $26.4 \pm 1.2$ & $25.5 \pm 0.4$ & $25.7 \pm 0.6$ \\
Body weight $(\mathrm{g})$ & $481.0 \pm 30.51$ & $475.3 \pm 17.9$ & $479.6 \pm 8.5$ \\
Ovulation rate (\%) & 100 & 100 & 100 \\
Fertilization rate $(\%)$ & $72.0 \pm 2.0^{\mathrm{a}}$ & $89.3 \pm 3.2^{\mathrm{b}}$ & $79.3 \pm 5.1^{\mathrm{a}}$ \\
Hatching rate $(\%)$ & $73.5 \pm 1.8^{\mathrm{b}}$ & $79.5 \pm 0.9^{\mathrm{c}}$ & $64.4 \pm 4.6^{\mathrm{a}}$ \\
Survival rate $(\%)$ & $50.7 \pm 2.31^{\mathrm{b}}$ & $67.0 \pm 2.0^{\mathrm{c}}$ & $46.0 \pm 1.0^{\mathrm{a}}$ \\
\hline
\end{tabular}


Induced spawning and larval development of vietnamesekoi, ..... (Md. Imtiaz Rahman)

Table 2. Fecundity of A. testudineus from April to June 2018

\begin{tabular}{lccc}
\hline \multirow{2}{*}{ Parameters } & \multicolumn{3}{c}{ Month } \\
\cline { 2 - 4 } & April & May & June \\
\hline No. of fish examined & 10 & 10 & 10 \\
Total length (cm) & $25.5 \pm 1.62^{\mathrm{a}}$ & $27.8 \pm 0.91^{\mathrm{b}}$ & $26.2 \pm 1.70^{\mathrm{a}}$ \\
Body weight (g) & $477.9 \pm 40.29^{\mathrm{a}}$ & $545.9 \pm 31.81^{\mathrm{b}}$ & $492.6 \pm 42.28^{\mathrm{a}}$ \\
Fecundity & $47,227 \pm 3423^{\mathrm{a}}$ & $77,561 \pm 5,917^{\mathrm{c}}$ & $65,295.7 \pm 5,608^{\mathrm{b}}$ \\
\hline
\end{tabular}

exterior and equipped with a buoyancy feature. The mean size of egg was measured $77.6 \pm 3.5 \mu \mathrm{m}$ in diameter. The first cleavage appeared at roughly 1825 min of fertilization (Figure 1.B) and finished around after $40 \mathrm{~min}$ to generate the first set of blastomeres (Figure 1.C), and then average diameter was $74.4 \pm$ $4.1 \mu \mathrm{m}$. The second cleavage (4 cell stage) was noted at $1 \mathrm{~h}$ and $15 \mathrm{~min}$ (Figure 1.D-E) and average diameter was $78.3 \pm 4.8 \mu \mathrm{m}$. third cleavage produced 8 blastomere cells within 1:30 h of post-fertilization and mean diameter was $69.7 \pm 8.7 \mu \mathrm{m}$ (Figure 1.F). Production of blastomere cells increased as time passed and reached 16, 32, 64, 128 cells within $1 \mathrm{~h}$ and $55 \mathrm{~min}, 2 \mathrm{~h}$ and $30 \mathrm{~min}, 2 \mathrm{~h}$ and $55 \mathrm{~min}$ and $3 \mathrm{~h}$ and 10 min respectively after fertilization and mean diameter were observed $79.8 \pm 2.8 \mu \mathrm{m}, 79.1 \pm 1.30$ $\mu \mathrm{m}, 81.1 \pm 1.6 \mu \mathrm{m}$, and $79.1 \pm 1.8 \mu \mathrm{m} \mathrm{mm}$ respectively (Figure 1.G, 1.H, and 1.I). The division of embryo remained continued and developed into ball of cells, termed as morula, at about $4 \mathrm{~h}$ after fertilization (Figure 1.J) and the blastocoel begins densely invaded by yolk sac growth.
The cell division pattern became poorly synchronized which make cell counting complicated (Figure 1.K). At about $5 \mathrm{~h} 50 \mathrm{~min}$, the commencement of gastrulation was remarked by resettlement cells (Figure 1.L), and distinction of embryonic tissue started by the end of this phase and three discrete layers were clearly detected (Figure 1.M). The neurula stage developed to be appeared between at $7 \mathrm{~h}$ and $40 \mathrm{~min}$ - $9 \mathrm{~h}$ (Figure 1.N) and organogenesis were clearly noticed at $9 \mathrm{~h} 30 \mathrm{~min}$ (Figure 1.0). The appendage of the larvae was generated at $13 \mathrm{~h}$ of fertilization (Figure 1.P). The plasma transmission was distinguished, and the movement of the tail appendage was visibly detectable at $15 \mathrm{~h}$. Larvae with definite head, body and tail surfaced between $17 \mathrm{~h}-19 \mathrm{~h}$ (Figure 1.Q). The eyes and mouth were detectable but not entirely developed (Figure 1.R). The free moving larvae was appeared between $19 \mathrm{~h}-22 \mathrm{~h}$ after fertilization (Figure 1.S). The larvae were containing oval yolk sac and some melanophores were spotted throughout the body, head, and somites.

Table 3. Time of different embryonic stages after fertilization in A. testudineus

\begin{tabular}{cccc}
\hline Figure No. & Development stages & $\begin{array}{c}\text { Egg size }(\boldsymbol{\mu m}) \\
(\mathbf{m e a n} \pm \mathbf{S D})\end{array}$ & $\begin{array}{c}\text { Development time } \\
(\mathbf{h}: \mathbf{m i n})\end{array}$ \\
\hline $\mathrm{A}$ & Fertilized egg & $77.59 \pm 3.50$ & $0 \mathrm{~min}$ \\
$\mathrm{~B}$ & Blastodisc formation & $74.56 \pm 5.94$ & $18-25 \mathrm{~min}$ \\
$\mathrm{C}$ & $2-$ cell & $74.36 \pm 4.14$ & $30-40 \mathrm{~min}$ \\
$\mathrm{D}$ & $4-$ cell & $78.30 \pm 4.86$ & $1 \mathrm{~h}$ and $15 \mathrm{~min}$ \\
$\mathrm{E}$ & $8-$ cell & $79.76 \pm 8.72$ & $1 \mathrm{~h}$ and $30 \mathrm{~min}$ \\
$\mathrm{~F}$ & $16-$ cell & $79.88 \pm 2.85$ & $1 \mathrm{~h} 45-1 \mathrm{~h} 55 \mathrm{~min}$ \\
$\mathrm{G}$ & $32-$ cell & $79.12 \pm 1.30$ & $2 \mathrm{~h}$ and $30 \mathrm{~min}$ \\
$\mathrm{H}$ & $64-$ cell & $81.17 \pm 1.62$ & $2 \mathrm{~h}$ and $55 \mathrm{~min}$ \\
I & $128-$ cell & $79.12 \pm 1.84$ & $3 \mathrm{~h}$ and $10 \mathrm{~min}$ \\
$\mathrm{~J}$ & Morula & $77.59 \pm 2.30$ & $3 \mathrm{~h}$ and $10 \mathrm{~min}-4 \mathrm{~h}$ \\
$\mathrm{~K}$ & Blastula & $75.88 \pm 2.33$ & $4 \mathrm{~h}-5 \mathrm{~h} 40 \mathrm{~h}$ \\
$\mathrm{~L}-\mathrm{M}$ & Gastrula & $74.65 \pm 0.92$ & $5 \mathrm{~h}$ and $50 \mathrm{~min}-7 \mathrm{~h}$ and $40 \mathrm{~min}$ \\
$\mathrm{~N}$ & Neurula & $74.59 \pm 1.90$ & $7 \mathrm{~h}$ and $40 \mathrm{~min}-9 \mathrm{~h} 25 \mathrm{~min}$ \\
O-R & Segmentation & $73.00 \pm 0.75$ & $9 \mathrm{~h}$ and $30 \mathrm{~min}-19 \mathrm{~h}$ \\
$\mathrm{~S}$ & Newly hatched larvae & $105.41 \pm 3.73$ & $19 \mathrm{~h}-22 \mathrm{~h}$ \\
\hline
\end{tabular}




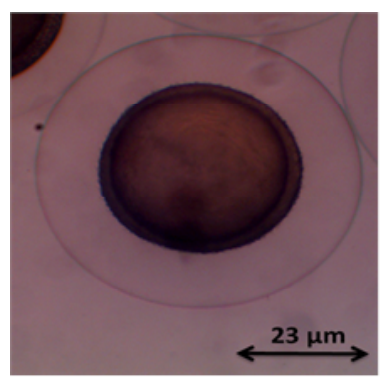

A

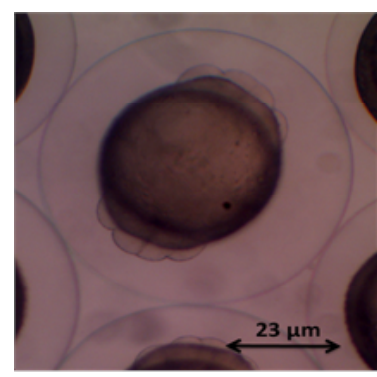

$\mathrm{E}$

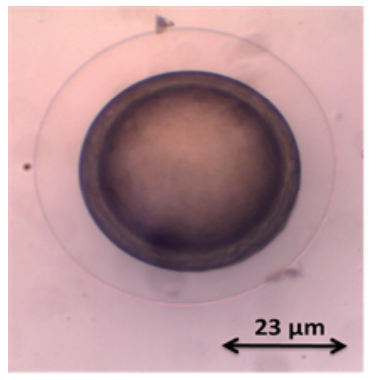

।

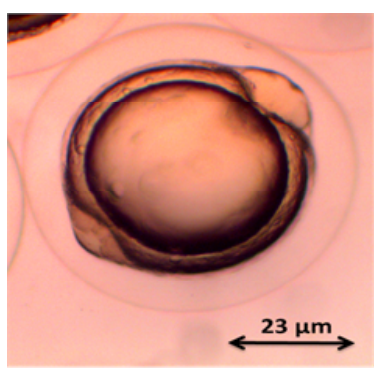

M

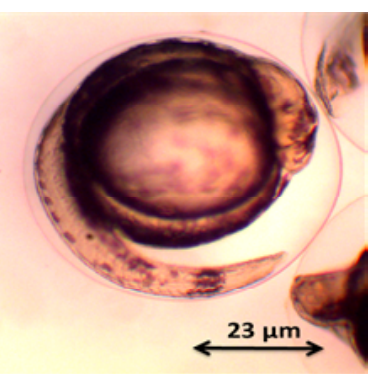

Q

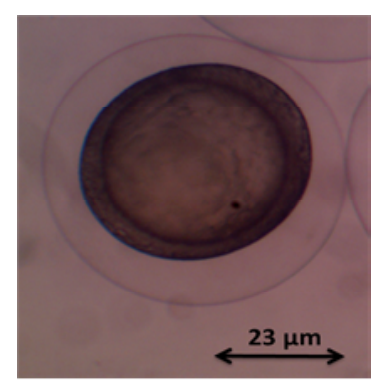

B

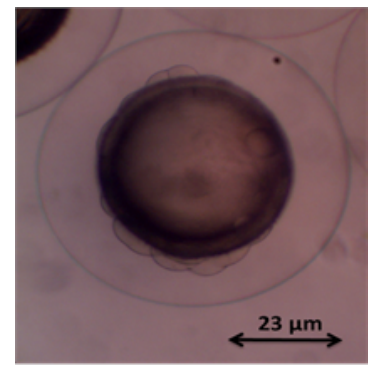

F

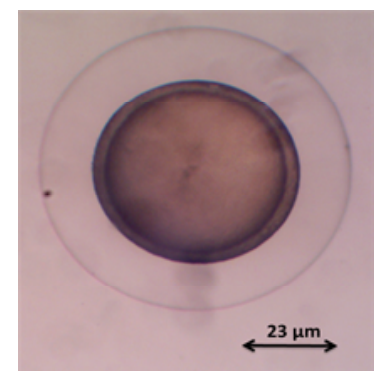

J

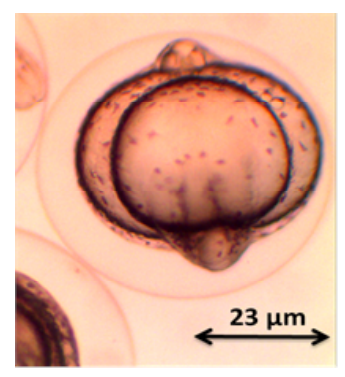

N

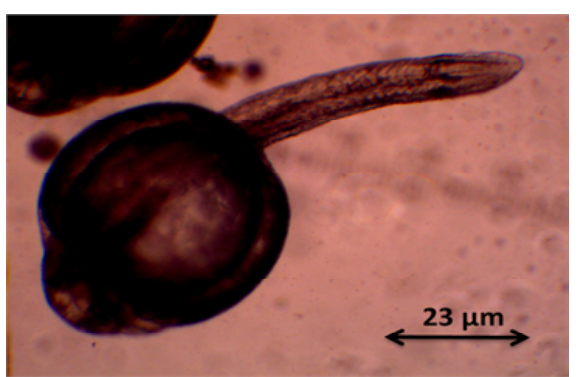

$\mathrm{R}$

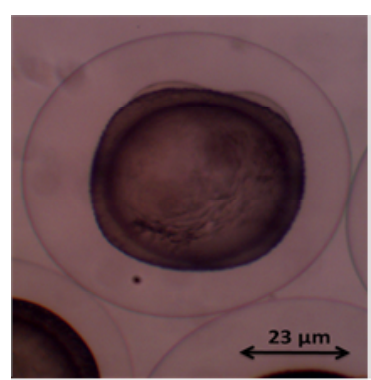

C

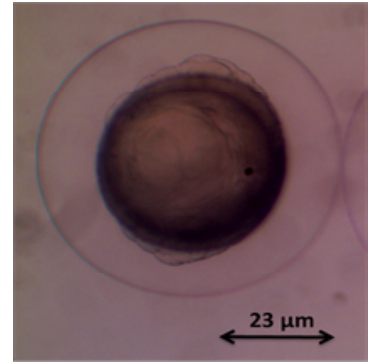

G

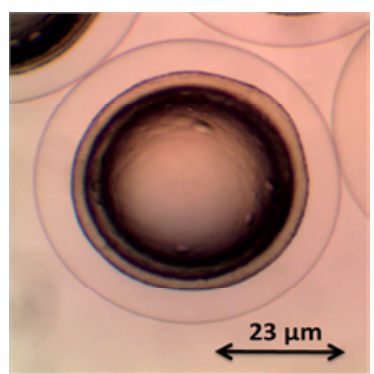

K

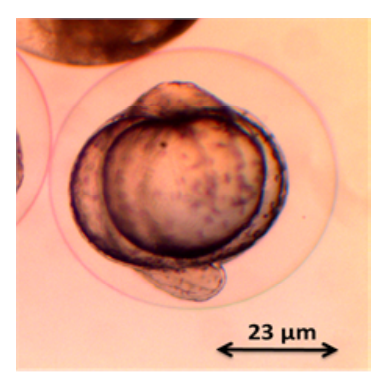

0

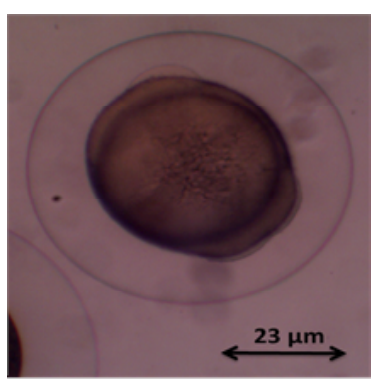

D

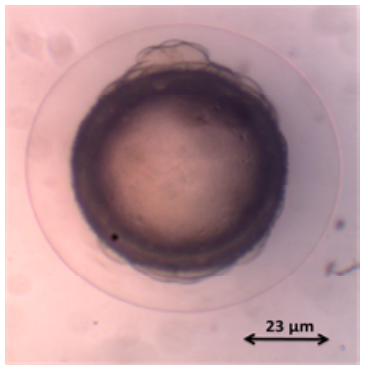

H

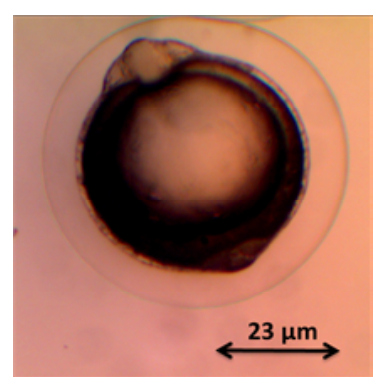

L

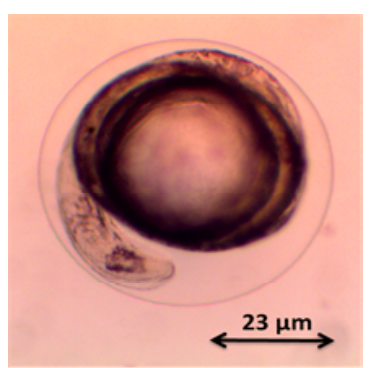

P

Figure 1. Developmental stages of $A$. testudineus. (a) fertilized egg, (b) blastodisc formation, (c) 2-cell stage, (d) 4-cell stage, (e) 8-cell stage, (f) 16-cell stage, (g) 32-cell stage, (h) 64-cell stage, (i) 128-cell stage, (j) morula, (k) blastula, (l) early gastrula, (m) late gastrula, (n) early neurula, (0)(r) segmentation, (r) newly hatched larva, (s) 15 h old larva (148.24 $\mu \mathrm{m})$. 
The first cleavage phase had been initiated at almost 18 min after fertilization and finalized after 40 min of fertilization. The second cleavage phase was commented at $1 \mathrm{~h}$ and $15 \mathrm{~min}$ and the 8, 16, 32, 64, 128 multiplication phases commenced within $3 \mathrm{~h}$ and $10 \mathrm{~min}$. The penetration blastoderm onto the yolk was completed after $7 \mathrm{~h}$ of spawning. Around 1-2 $\mathrm{h}$ prior to hatching, the embryo exhibit curving arrangements towards the egg envelops. The post spawning incubation cycle had lasted for $20 \mathrm{~h}$ at a water temperature of $26^{\circ} \mathrm{C}$ in current study. The newly hatched larva had been measured as $105.41 \pm 3.73 \mu \mathrm{m}$ in length in current research. A measure of $1.8 \mathrm{~mm}$ had been observed for newly hatched larvae of the same species (Zalina et al., 2012). Several previous noted considerable durations for embryonic development in fish and it depends upon rearing temperature and species as well.

\section{CONCLUSIONS}

The present study revealed that $0.5 \mathrm{~mL} / \mathrm{kg}$ dose of S-GnRHa showed maximum performance in respect of fertilization and hatching rate, survival rate of $A$. testudineus which can be used for successful artificial breeding of this species. The comprehensive knowledge about the embryonic expansion of $A$. testudineus have been recorded in this investigation which will help hatchery owner for efficient and successful breeding.

\section{REFERENCES}

Ahamed, S., Hasan, K., Mou, M., \& Mursalin, M. (2018). Polyculture of Vietnamese koi (Anabas testudineus): Emphasis on seasonal mini water ponds in semiarid zone of Bangladesh. Annual Research \& Review in Biology, 27(6), 1-7. https://doi.org/10.9734/ARRB/ 2018/42123.

Aktar, N. (2015). Induced breeding practices of the fish hatcheries in the north-western Region of Bangladesh. Journal of Aquaculture \& Marine Biology, 2(6), 1-5. https://doi.org/10.15406/ jamb.2015.02.00048.

Amin, M.R., Rahman, M.M., Aktar, S., Alam, M.B., \& Alam, M.A. (2016). Induced breeding of Vietnamese koi (Anabas testudineus) using pituitary gland (PG) and ovaprim at Tasty Fish and Feeds Industries Limited, Melandah, Jamalpur. Asian Journal of Medical and Biological Research, 1(3 SE-Articles). https://doi.org/10.3329/ajmbr.v1i3.26484.

Ara, I. \& Nabi, M.R. (2018). Morphometric and meristic comparison of local and Thai Anabas testudineus. Journal of Fisheries, 6(2), 599-604. http:// journal.bdfish.org/index.php/fisheries/article/view/ JFish_79.
Behera, S., Ahmed, A.S., Kumar, S., Gogoi, R., Jomang, 0., \& Baksi, S. (2016). Courtship behaviour and breeding success of Climbing Perch, Anabas testudineus (Bloch) in three different breeding sets with the application of a synthetic hormone (WOVA-FH). International Journal of Fisheries and Aquatic Studies, 6(1), 1-6.

Bhattacharyya, M. \& Homechaudhuri, S. (2009). Assessment of captive breeding of Anabas testudineus with the synthetic hormone, Ovaprim. Proceedings of the Zoological Society, 62, 23-27. https://doi.org/10.1007/s12595-009-0003-7.

Faruk, A., Hossain, A., Asif, A., Nurul Mahmud Bhuiyan, M., \& Sarker, M. (2018). Culture and management techniques of Vietnamese Koi. Asian Australasian Journal of Bioscience and Biotechnology, 3(2), 93105.

Ganias, K. (2017). Fecundity. In: Vonk, J. \& Shackelford, T. (Eds.). Encyclopedia of Animal Cognition and Behavior. Springer, Cham. https://doi.org/10.1007/ 978-3-319-47829-6_221-1.

Hassan, A, Okomoda, V.T., \& Sanusi, F.A.B. (2018). Fertilization, hatching, and embryogenesis of diploid and triploid eggs of Anabas testudineus (Bloch, 1792). Zygote, 5, 343-349. http://doi.org/10.1017/ S0967199418000187.

Helmizuryani, D.M.B., Aminah, R.I.S., \& Khotimah, K. (2020). The gonadal maturation of climbing perch, Anabas testudineus (Bloch, 1792) with dietary supplement add on feed. AACL Bioflux, 13(2), 885-892.

Hossen, B., Sharker, R., Rahman, A., \& Hoque, S. (2017). Morphometric and meristic variation of indigenous and Thai Koi, Anabas testudineus available in coastal region of Bangladesh. International Journal of Innovative Research, 2(1), 1-8.

Khatun, D., Hossain, Y., Rahman, A., Islam, A., Rahman, O., Azad, A.K., Sarmin, M.S., ....., \& Hossain, A. (2019). Life-History traits of the climbing perch Anabas testudineus (Bloch, 1792) in a wetland ecosystem. Jordan Journal of Biological Sciences, 12(2), 175-182.

Kiran, B.R., Shankar M.K., \& Venkateshwarlu, M. (2013). A review on induced breeding of catfishes, murrels and climbing perches in India. Pelagia Research Library Advances in Applied Science Research, 4(4), 310-323.

Kumar, P., Kailasam, M., Biswas, G., Christina, L., \& Ghoshal, T.K. (2021). Effect of different inducing hormones, sex ratio and oocyte diameter on breeding performance of brackish water catfish, Mystus gulio. Aquaculture, 530, 735821. https:// do i.org/https://doi .org/10.1016/ j.aquaculture.2020.735821. 
Legendre, M. (2000). Taux d'ovulation, temps de latence et viabilit $\tilde{A} \odot$ des ovules aprã " $s$ induction de l'ovulation avec GnRH ou hCG chez le poissonchat asiatique Pangasius hypophthalmus (Siluriformes, Pangasiidae). Aquatic Living Resources, 13(3), 145-151. https://doi.org/10.1016/S09907440(00)00148-0.

Loh, J.Y. \& Ting, A.S.Y. (2015). Comparative study of analogue hormones and the embryonic, larval and juvenile development on the induced breeding of climbing perch (Anabas testudineus, Bloch, 1792). International Journal of Fisheries and Aquatic Studies, 2(5), 277-284.

Mandal, B., Kumar, R., \& Jayasankar, P. (2016). Efficacy of exogenous hormone ( $\mathrm{GnRHa}$ ) for induced breeding of climbing perch Anabas testudineus (Bloch, 1792) and influence of operational sex ratio on spawning success. Animal Reproduction Science, 171, 114-120. https://doi.org/https:// doi.org/10.1016/j.anireprosci.2016.06.006.

Mondal, M.N., Shahin, J., Wahab, M.A., Asaduzzaman, M., \& Yang, Y. (2010). Comparison between cage and pond production of Thai climbing perch (Anabas testudineus) and tilapia (Oreochromis niloticus) under three management systems. Journal of the Bangladesh Agricultural University, 8(2): 313-322.

Muslimin, B., Khotimah, K., Jenderal, Y.J.A., Ulu, S.I., \& Selatan, S. (2018). Reproduction performance of climbing perch Anabas testudineus F1 and F2 broodstock with different dietary supplementation. Jurnal Akuakultur Indonesia, 17(1), 61-67. https://doi.org/10.19027/jai.17.1.61-67.

Nabi, M.M., Halim, A., \& Nahar, S. (2020). Study the production performance of climbing perch (Vietnamese Koi-Anabas testudineus) in dewatering canal at BAPARD campus, Gopalganj. International Journal of Fisheries and Aquatic Research, 5(1), 19-23.

Paul, B.N., Chanda, S., Bhowmick, S., Sridhar, N., Saha, G.S., \& Giri, S.S. (2017). Nutrient profile of Indian climbing perch, Anabas testudineus. SAARC Journal of Agriculture, 15(1 SE-Articles). https://doi.org/ 10.3329/sja.v15i1.33156.
Rahman, M.M. \& Samat, A.F. (2020). Reproductive cycle, sexual maturity and fecundity of Nemipterus furcosus (Valenciennes, 1830). Aquaculture and Fisheries. https://doi.org/https://doi.org/10.1016/ j.aaf.2020.07.006.

Raze, M.S., Bosu, A., Roy, B.C., \& Moniruzzaman, M. (2017). Determination of optimized dose with synthetic hormone for induced spawning of vietnamese koi (Anabas testudineus). International Journal of Natural and Social Sciences, 4(1), 95-102.

Sarkar, U.K., Deepak, P.K., Kapoor, D., Negi, R.S., Paul, S.K., \& Singh, S. (2005). Captive breeding of climbing perch Anabas testudineus (Bloch, 1792) with Wova-FH for conservation and aquaculture. Aquaculture Research, 36(10), 941-945. https://doi.org/ 10.1111/j.1365-2109.2005.01281.x.

Sukendi, Windarti, Putra, R.M., \& Eddiwan. (2019). Hormone induced spawning and feeding conditions for betok fish (Anabas testudineus). EurAsian Journal of BioSciences, 13(1), 121-125.

Tsadik, G.G. \& Bart, A.N. (2007). Effects of feeding, stocking density and water-flow rate on fecundity, spawning frequency and egg quality of nile tilapia, Oreochromis niloticus (L.). Aquaculture, 272(1), 380-388. https://doi.org/https://doi.org/10.1016/ j.aquaculture.2007.08.040.

Uddin, S., Hasan, M.H., Iqbal, M.M., \& Hossain, M.A. (2017). Study on the reproductive biology of Vietnamese climbing perch (Anabas testudineus, Bloch). Punjab University Journal of Zoology, 32(1), 1-7.

Unuma, T., Kondo, S., Tanaka, H., Kagawa, H., Nomura, K., \& Ohta, H. (2004). Determination of the rates of fertilization, hatching and larval survival in the Japanese eel, Anguilla japonica, using tissue culture microplates. Aquaculture, 241(1-4), 345-356. https://doi.org/10.1016/j.aquaculture.2004.08.005.

Zalina, I., Saad, C.R., Christianu, A., \& Harmin, S.A. (2012). Induced breeding and embryonic development of climbing perch (Anabas testudineus, Bloch). Journal of Fisheries and Aquatic Science, 7(5), 291-306. https://doi.org/10.3923/jfas.2012. 291.306. 